\title{
Tight junctions at the blood brain barrier: physiological architecture and disease-associated dysregulation
}

\author{
Anny-Claude Luissint ${ }^{1,2,3}$, Cédric Artus ${ }^{1,2,3}$, Fabienne Glacial 1,2,3, Kayathiri Ganeshamoorthy ${ }^{1,2,3}$ \\ and Pierre-Olivier Couraud ${ }^{1,2,3^{*}}$
}

\begin{abstract}
The Blood-brain barrier (BBB), present at the level of the endothelium of cerebral blood vessels, selectively restricts the blood-to-brain paracellular diffusion of compounds; it is mandatory for cerebral homeostasis and proper neuronal function. The barrier properties of these specialized endothelial cells notably depend on tight junctions (TJs) between adjacent cells: TJs are dynamic structures consisting of a number of transmembrane and membrane-associated cytoplasmic proteins, which are assembled in a multimolecular complex and acting as a platform for intracellular signaling. Although the structural composition of these complexes has been well described in the recent years, our knowledge about their functional regulation still remains fragmentary. Importantly, pericytes, embedded in the vascular basement membrane, and perivascular microglial cells, astrocytes and neurons contribute to the regulation of endothelial TJs and BBB function, altogether constituting the so-called neurovascular unit.

The present review summarizes our current understanding of the structure and functional regulation of endothelial TJs at the BBB. Accumulating evidence points to a correlation between BBB dysfunction, alteration of TJ complexes and progression of a variety of CNS diseases, such as stroke, multiple sclerosis and brain tumors, as well as neurodegenerative diseases like Parkinson's and Alzheimer's diseases. Understanding how TJ integrity is controlled may thus help improve drug delivery across the BBB and the design of therapeutic strategies for neurological disorders.
\end{abstract}

Keywords: Blood-brain barrier, Tight junction, Neurovascular unit, Kinases, Signaling pathways

\section{Review}

\section{Background}

The BBB maintains the homeostasis of the central nervous system (CNS) by (i) strictly limiting the passive diffusion of polar substances from the blood to the brain, (ii) mediating the transport of nutrients to the brain parenchyma as well as the efflux from the brain of toxic metabolites and xenobiotics, (iii) regulating the migration of circulating immune cells [1-3]. Formed by specialized vascular endothelial cells, the BBB is tightly controlled by pericytes, embedded in the vascular basement membrane, perivascular microglial cells, astrocytes and neurons which

\footnotetext{
* Correspondence: pierre-olivier.couraud@inserm.fr

'INSERM U1016, Institut Cochin, Paris, France

${ }^{2}$ CNRS, UMR 8104, Paris, France

Full list of author information is available at the end of the article
}

altogether constitute the neurovascular unit (NVU), a concept highlighting the functional cell-cell interactions supporting BBB function.

BBB endothelial cells display a unique phenotype characterized by the presence of TJs and the expression of specific polarized transport systems. TJs constitute the most apical intercellular junctional complex in polarized epithelium and endothelium, with three key biological functions: a barrier to paracellular diffusion of bloodborne polar substances [4], a fence preventing the lateral diffusion of lipids and integral membrane proteins, thus maintaining cell polarization [5-7] and an intracellular signaling platform which will be described below.

Brain endothelial TJ strands, like epithelial TJs, are composed of integral membrane proteins (occludin, claudins and junctional adhesion molecules (JAMs))

\section{Biomed Central}


involved in intercellular contacts and interactions with cytoplasmic scaffolding proteins such as zonula occludens (ZO) proteins, actin cytoskeleton and associated proteins, such as protein kinases, small GTPases [8] and heterotrimeric G-proteins [9].

Excellent reviews have recently been published on the architecture of TJ complexes in epithelial and brain endothelial cells $[10,11]$. Here we will briefly recall the main features of the structural organization of TJs at the $\mathrm{BBB}$ and will focus on transcriptional regulation, posttranslational modifications and subcellular localization of $\mathrm{TJ}$ proteins and their consequences for BBB integrity with exposure to various environmental stimuli and during CNS disorders.

\section{Components of TJs in brain endothelial cells}

As in polarized epithelial cells where TJs have been mostly studied, the TJ backbone in brain endothelial cells consists of transmembrane proteins (occludin, claudins and JAMs) which recruit a number of membrane-associated cytoplasmic proteins.

\section{Transmembrane proteins as the BBB TJ backbone}

Occludin $(60 \mathrm{kDa})$, a tetraspan integral membrane protein, was the first TJ-specific protein identified $[12,13]$ in epithelial cells and shown to be functionally important for barrier function [14]. It is a member of the family of TJ-associated marvel proteins (TAMP) with tricellulin (marvelD2) [15] and marvelD3 [16,17]. Both the MARVEL transmembrane domain of occludin, encompassing the four transmembrane helices, and its coiled coil cytosolic C-terminus were recently described to mediate its lateral (i.e. cis-) oligomerization in epithelial MDCK cells [18-20]. More precisely, cystein residues in these domains are directly involved in oligomerization through disulfide bridge formation. This process being redox-sensitive, oligomerization of occludin likely contributes to the redox-dependency of the TJ assembly [20,21]: whereas normoxia conditions support occludin oligomerization and contribute to TJ assembly, oxidative stress associated with hypoxia-reoxygenation [22] or inflammation $[23,24]$ results in TJ disruption. This novel concept that occludin plays a key role in the redox regulation of TJs has been very recently reviewed [25].

In addition, the second extracellular domain of occludin is required for its stable assembly in TJs [26]. Indeed, synthetic peptides corresponding to this domain were shown to perturb TJ permeability barrier in epithelial cells [27-29]. The important contribution of occludin to TJ function is illustrated by the observations that ectopic expression of chicken occludin induced the formation of TJ-like structures in Sf9 insect cells [30], while increasing electrical resistance in MDCK cells [31]. Conversely, occludin degradation induced by viruses or bacteria (like
HIV-1 Tat protein or Neisseria meningitidis), is associated with increased permeability in primary or immortalized human brain microvascular endothelial cells, respectively $[32,33]$. However, well-developed TJ strands were reported in cells lacking occludin (human or guinea pig testis) [34] and between adjacent occludin-deficient epithelial cells [34,35]; together with the report that occludin deficientmice are viable, exhibiting normal TJs morphology as well as intestinal epithelium barrier function, these observations indicate that occludin is dispensable for $\mathrm{TJ}$ formation [36,37].

Claudins constitute a large family of $20-27 \mathrm{kDa}$ membrane proteins (with four transmembrane domains) expressed in TJs in various cell types [4,38-40] (endothelial and epithelial cells). Brain endothelial cells predominantly express claudin-3 and claudin-5 [41,42], claudin-12 likely being also expressed $[43,44]$. A large corpus of data clearly establishes the key contribution of claudin-3 and claudin-5 to TJ formation and integrity at the BBB. Indeed, exogenous expression of claudin-5 strengthens barrier properties in cultured rat brain endothelial cells [44], whereas depletion of claudin-5 induces the disruption of the BBB in genetically-altered mice [43] and in cultured human brain endothelial cells [9]. Claudins support TJ integrity via their capacity of cis- and transhomodimerization as well as heterodimerization, notably through their second extracellular loop, as recently reported for claudin-5 [45-47]. Claudin-5 can interact with claudin-3 $[48,49]$ and the selective loss of the latter during autoimmune encephalomyelitis or human glioblastoma is associated with BBB breakdown [41].

Beside occludin and claudins, JAMs, although not essential to $\mathrm{TJ}$ formation in epithelial and endothelial cells, may be involved in the facilitation of assembly of TJ components and in the establishment of cell polarity by recruiting the polarity complex (Par-3/Par-6/aPKC: see below) to TJs $[50,51]$.

\section{Membrane-associated cytoplasmic proteins in BBB TJs}

A number of cytoplasmic proteins have been described to associate with TJ transmembrane proteins and to contribute somehow to TJ integrity in epithelial and brain endothelial cells. Among them, the PDZ domaincontaining, membrane-associated guanylate kinase (MAGUK) family members have been largely documented: zonula occludens-1 (ZO-1, 225kDa) [52], ZO-2 (160kDa) [53], and ZO-3 (130kDa) [54]. ZO-1 forms heterodimers with $\mathrm{ZO}-2$ and $\mathrm{ZO}-3$ [54-56]. $\mathrm{ZO}$ proteins interact with the C-terminal domain of claudins via their first PDZ domain (PDZ1) [57], to JAMs by the third PDZ domain (PDZ3) [58] and to occludin via their GUK domains [55,56,59]. It is well established that $\mathrm{ZO}$ proteins are essential to the assembly of claudins [60], occludin [35] and JAM-A [61] at TJs, then anchoring this multimolecular complex to 
the actin cytoskeleton [62]. Par-3 (also known as ASIP) [63] binds to JAM proteins [64-66] and recruits to TJs atypical protein kinase $C$ [67] and Par-6 [68], the three proteins then forming a Planar Cell Polarity (PCP) complex in polarized epithelial cells [69]. Only very recently was their expression confirmed also in brain endothelial cells [70].

Among additional TJ-associated proteins, heterotrimeric G-proteins (Gai) were first described, in association with $\mathrm{ZO}-1$, to contribute to TJ biogenesis and maintenance in epithelial and brain endothelial cells [71-73]. Goi2 proteins were reported to be involved in T-lymphocyte extravasation, including in brain [74,75]. More recently, we reported that Goi2 interacts with claudin-5 and that its depletion increases brain endothelial cell permeability in vitro and delays TJ reassembly after hyperosmotic shock (induced by a high concentration mannitol treatment) [9]. On the basis of these observations, we proposed that claudin- 5 and Goi2, whether they interact directly or indirectly, might control TJ integrity as components of a multiprotein complex, including caveolin, ZO-1 linked to the actin cytoskeleton and possibly also, occludin and MUPP-1.

\section{Physiological regulation of $\mathrm{TJ}$ assembly by the NVU}

The NVU: regulation of $\mathrm{TJ}$ assembly by perivascular cells

Developmental role of astrocyte and pericyte secreted proteins

Development and maintenance of the $\mathrm{BBB}$ requires functional interactions between endothelial cells and perivascular cells of the NVU: whereas astrocytes have been well documented to regulate BBB formation and integrity $[76,77]$, only recently was the role of pericytes unraveled (for reviews: [78-80]).

Indeed, early studies using co-culture of cerebral endothelial cells and astrocytes (or culture in the presence of astrocyte-conditioned medium) [81-87] highlighted the role of astrocyte-derived soluble factors in maintaining the specialized phenotype of brain endothelial cells (Figure 1). In addition, more recent reports established that pericytes also actively contribute to $\mathrm{BBB}$ formation during development by the release of several growth factors and morphogens [88-91].

Astrocyte- and pericyte-derived Wnt and hedgehog morphogens were reported to control BBB formation during development and TJ integrity. Indeed, the Wnt/ $\beta$-catenin pathway has been recently discovered as a major BBB-regulating pathway. Wnt ligation to its membrane receptors, Frizzled4 (Fz4) and LRP5/6 expressed by brain endothelial cells, inhibits the $\beta$-catenin repressor complex, allowing $\beta$-catenin cytoplasmic accumulation, nuclear translocation and transcription of various genes, including claudin-3 in cultured murine brain endothelial cells $[96,99]$ (Figure 1). Moreover, in vivo inactivation of Wnt factors (Wnt7a and Wnt7b) [100], Fz4 receptor [101] or injection of a soluble inhibitor of the Wnt/ Frizzled receptor interaction [102] lead to major vascular defects in the CNS (interestingly, not in non-neuronal tissues) and to BBB breakdown, clearly demonstrating a specific role for the $\mathrm{Wnt} / \beta$-catenin pathway in $\mathrm{BBB}$ differentiation during development and for BBB maintenance in adulthood. These exciting observations (for review, see: [103]) open new research avenues for controlling BBB permeability in pathological situations as well as improving drug delivery to the CNS.

Sonic hedgehog (Shh), another well-known morphogen protein, acting through its membrane receptors Patched1 (Ptch1)/Smoothened (Smo), was also recently shown to control BBB differentiation and to maintain the immune privilege of the CNS by inhibiting the endothelial production of chemokines and expression of adhesion proteins supporting extravasation of leukocytes to the brain [95].

In conclusion, these recent findings further document, at the molecular and cellular levels, the functional interactions between brain endothelial cells, pericytes and astrocytes and emphasise the key importance of the NVU in controlling BBB permeability and integrity. The major cellular cross-talks at the NVU are illustrated in Figure 1.

\section{Role of basement membrane-associated proteins}

The vascular basement membrane (or basal lamina) is a complex structure, composed of four glycoprotein families: laminins, collagen type IV, nidogens and heparan sulfate proteoglycans. Recent studies have unraveled the contribution of the endothelial laminin isoform $\alpha 5$ to the barrier property of the $\mathrm{BBB}$ by selectively inhibiting lymphocyte infiltration; the basement membrane thus contributes to maintain the well-known "immune privilege" of the CNS [104].

The heparan sulfate proteoglycan agrin is found in the basal lamina of brain microvessels [105]. A strict positive correlation has been reported between agrin deposition and expression of occludin [106], whereas, conversely, absence of agrin in glioblastoma vessels was shown to correlate with the lack of TJ proteins (occludin, claudin-5): these observations strongly suggest that agrin may regulate $\mathrm{TJ}$ formation in brain endothelium. Recently, agrin was described to be involved in the development of the BBB by contributing to astrocyte polarity [92]. Moreover, $\beta 1$-integrin-mediated attachment of brain endothelial cells to the basement membrane has also been reported to be critical for stabilizing claudin- 5 localization at TJs and maintaining $\mathrm{BBB}$ integrity in vitro and in vivo [93]. Genetic deletion of $\beta 1$-integrin decreases the expression of the polarity protein Par-3, leading to the loss of endothelial cell polarity: these recent data 


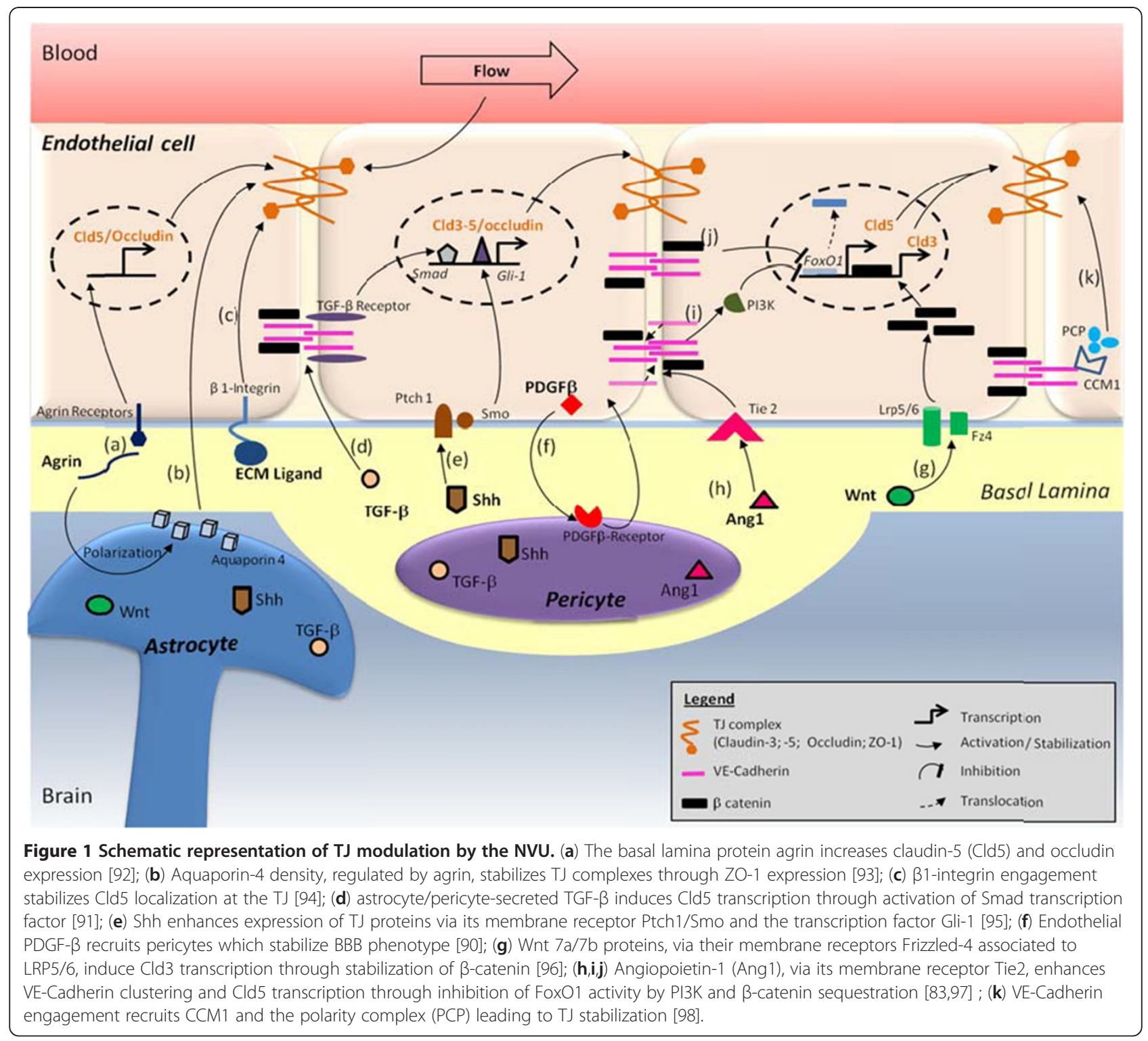

suggest that $\beta 1$-integrin-mediated brain endothelial cell adhesion to the basement membrane may lead to the development of cell polarity, $\mathrm{TJ}$ formation and $\mathrm{BBB}$ integrity [94].

\section{VE-cadherin and $\beta$-catenin as modulators of TJs}

In addition to TJs, junctional complexes between endothelial cells include adherens junctions (AJs), constituted by transmembrane proteins VE-cadherin linked to the actin cytoskeleton through catenins (eg: p120-catenin, $\alpha$ - and $\beta$-catenin) [107-109]. Interestingly, $\mathrm{AJ}$ and $\mathrm{TJ}$ complexes functionally interact in brain endothelial cells: indeed, VE-cadherin engagement induces claudin-5 transcription through inhibition of FoxO1 activity (a transcription repressor of claudin- 5 gene) and $\beta$-catenin sequestration (a stabilizer of FoxO1 activity) in AJ complexes [97], in line with the above-mentioned capacity of $\beta$-catenin, downstream of Wnt receptor activation, to control claudin gene expression [96]. These findings clearly place VE-cadherin upstream of claudin- 5 in the establishment, maturation and maintenance of endothelial cell-cell junctions.

\section{Contribution of shear stress to TJ modulation and BBB integrity}

It is established that one important mechanical stimulus contributing to $\mathrm{BBB}$ formation and maintenance is shear stress [110], a tangential force generated by flow across the apical surface of vascular endothelium $[111,112]$. In line with the accepted concept that cerebral microcirculation is highly heterogeneous, mean shear stress levels in brain microvessels has been 
estimated in a range as wide as 0.01 to 10 dynes $/ \mathrm{cm}^{2}$ in capillaries and 10-100 dynes $/ \mathrm{cm}^{2}$ in arterioles [113-115]. Several dynamic in vitro models were developed in order to mimic a physiological situation (using laminar, steady flow) or a pathological condition (such as atherosclerosis), using an irregular flow. Interestingly, culturing human umbilical vein endothelial cells (HUVECs) in a laminar flow chamber in the presence of meningococci (N. meningitidis) was instrumental for unraveling some key molecular mechanisms of CNS invasion by these meningitis-causing human pathogens [111]. Regarding BBB differentiation, culture of brain endothelial cells under flow has been reported to induce the expression of the $\mathrm{TJ}$ proteins occludin and $\mathrm{ZO}-1$, to promote actin cytoskeleton reorganization and to reduce endothelial permeability [113,115-117]. In addition, very recent findings suggest that physiological shear stress $\left(6\right.$ dynes $\left./ \mathrm{cm}^{2}\right)$ may increase the expression of a variety of BBBassociated genes in human brain microvascular endothelial cells, such as genes encoding for $\mathrm{TJ}$ proteins (ZO1, claudin-3, claudin-5), several influx transporters
(Glut-1) and multidrug resistance efflux transporters (ABCB1/P-gp, ABCC5/MRP5) [116]. Nevertheless, further investigation is still required to get a better understanding of the contribution of shear stress to the maintenance of BBB integrity.

\section{Dysregulation of the BBB via phosphorylation and relocalization of $\mathrm{TJ}$ proteins}

Studies on CNS diseases associated with BBB dysfunctions (e.g. stroke, multiple sclerosis, cerebral infection, brain tumors, Parkinson's and Alzheimer's diseases) have pointed to various molecular mechanisms involved in disruption of TJ integrity, notably including Serine/Threonine (Ser/Thr)and Tyrosine (Tyr)-phosphorylation, down-regulation, degradation or translocation of TJ proteins; a non exhaustive list of related reports are presented in Table 1. More than other TJ proteins (such as claudins or JAMs), occludin has been the focus of numerous studies investigating post-translational modifications and their consequences on TJ integrity (see for review: $[118,119]$ ).

Table 1 Dysregulation of the BBB via phosphorylation or down-regulation of TJ proteins

\begin{tabular}{|c|c|c|c|c|}
\hline TJ proteins modifications & Targeted TJ proteins & Signaling pathway & Stimulus / Diseases & References \\
\hline \multirow{7}{*}{$\begin{array}{l}\text { Serine/Threonine } \\
\text { Phosphorylation }\end{array}$} & Cld5 (Thr207) & PKA & CAMP & {$[120]$} \\
\hline & Cld5, Occludin and ZO-1 & $\mathrm{nPKC}-\theta / \mathrm{aPKC}-\zeta$ & Hypoxia & [121] \\
\hline & N.D. & cPKC-a, cPKC- $\beta \|$, aPKC- $-\lambda / \zeta$ & HIV-1 gp120 & [122] \\
\hline & Cld5 (T207) Occludin (T382/S507) & RhoA/Rho kinase & HIV-1 encephalitis & [123] \\
\hline & Cld5, Occludin, ZO-1 & RhoA / PKC-a & CCL2 chemokine & [124] \\
\hline & Cld5 and Occludin & MLCK & Alcohol / Reactive oxygen species & {$[125,126]$} \\
\hline & N.D. & & Hypoxia / Reactive oxygen species & [127] \\
\hline \multirow[t]{4}{*}{ Tyrosine Phosphorylation } & Occludin & $\mathrm{c}-\mathrm{Src}$ & Cerebral ischemia & {$[128]$} \\
\hline & Occludin & N.D. & Glutamate & [129] \\
\hline & Cld5 & N.D. & TGF- $\beta$ & [130] \\
\hline & ZO-1 & ND & Tyrosine phosphatase inhibition & [131] \\
\hline \multirow[t]{11}{*}{$\begin{array}{l}\text { Down-regulation } \\
\text { or degradation }\end{array}$} & $\begin{array}{l}\text { Cld5 and Occludin } \\
\text { Internalization }\end{array}$ & $\begin{array}{l}\text { Caveolae-dependent } \\
\text { endocytosis }\end{array}$ & CCL2 chemokine & [132] \\
\hline & Occludin & JNK, p38MAPK & Amyloid- $\beta$ peptide & [133] \\
\hline & Cld5 & ERK $1 / 2$ & HIV-1 Tat protein & [134] \\
\hline & Occludin and ZO-1 distribution & PLC- $\gamma, \mathrm{PI} 3 \mathrm{~K} / \mathrm{Akt}$ & Hypoxia & [135] \\
\hline & & N.D. & & [136] \\
\hline & Cld5 & N.D. & & [137] \\
\hline & Cld5 and Occludin & VEGFR & VEGF & [138] \\
\hline & $\mathrm{Cld} 3$ & N.D. & $\begin{array}{l}\text { Multiple Sclerosis Glioblastoma } \\
\text { multiforme }\end{array}$ & [41] \\
\hline & Cld5, Occludin, ZO-1 & $n P K C-\delta$ & Cerebral ischemia & [139] \\
\hline & Occludin and ZO-1 & MLCK & HTLV-1 & [140] \\
\hline & Cld5 and Occludin & RhoA/RhoK & Reactive oxygen species & [141] \\
\hline
\end{tabular}




\section{Ser/Thr-phosphorylation of TJ proteins and regulation of barrier permeability}

Ser/Thr-phosphorylation forms of occludin are found concentrated at TJs whereas dephosphorylated occludin is rather detected on basolateral membranes and associated with disrupted TJs in epithelial cells [142,143] as well as in brain endothelial cells in experimental autoimmune encephalomyelitis, a murine model of multiple sclerosis characterized by brain inflammation [144]. Regarding claudin-5, phosphorylation of its C-terminal domain on Thr207 residue in response to PKA or Rho kinase activation $[120,123,145]$ generally affected TJ integrity in brain endothelial cells and increased permeability.

\section{Differential regulation of TJs by Protein Kinases C (PKCS)}

PKC-dependent pathways have been involved in endothelial barrier disruption, as reported following treatment by pertussis toxin, an inhibitor of Gai heterotrimeric G proteins [146], or in response to the pro-inflammatory cytokine interleukin-6 (IL-6) which plays a critical role during hypoxia [147]. However, early reports had clearly established that PKC activity was crucial for BBB integrity in epithelial cells, inasmuch as PKC inhibitors completely blocked the formation of TJs $[148,149]$; in addition, PKCmediated phosphorylation of occludin (on residue Ser338) was involved in occludin targeting to TJs and TJ stabilization in epithelial MDCK cells [148].

At least part of the interpretation of these apparently conflicting data may be found in the heterogeneity of the PKC family. The Ser/Thr-kinases PKCs are indeed classified into conventional (cPKC: $\alpha, \beta \mathrm{I}, \beta \mathrm{II}$ and $\gamma$ ), novel (nPKC: $\delta, \varepsilon, \theta, \eta, \mu)$ and atypical (aPKC: $\lambda, \zeta)$ PKC isozymes [150] according to their modes of regulation. Accumulating evidence has pointed to a differential capacity of $\mathrm{PKC}$ isozymes to regulate $\mathrm{BBB}$ permeability. Indeed, activation of $\mathrm{nPKC}-\theta$ and $\mathrm{aPKC}-\zeta$ signaling by hypoxia-mediated $\mathrm{TJ}$ proteins results in relocalization (such as claudin-5, occludin, ZO-1) and increased BBB permeability in rat brain microvascular endothelial cells (in vitro and in vivo) $[121,151]$. In human brain microvascular endothelial cells, $\mathrm{CPKC} \alpha, \mathrm{cPKC} \beta \mathrm{II}$ and $\mathrm{aPKC} / \zeta$ isoforms were activated by HIV-1 gp120 envelope protein, leading to BBB disruption, intracellular calcium increase and monocyte migration across cell monolayer [122]. Interestingly, when $\mathrm{cPKC}-\alpha$ was found to contribute to $\mathrm{TJ}$ disassembly, $\mathrm{nPKC}-\varepsilon$ activation mediated TJ formation in epithelial MDCK cells [152]. In line with this observation, over-expression of $c$ PKC- $\alpha$ in rat epididymal microvascular endothelial cells was reported to enhance thrombin-induced permeability, whereas $n P K C-\delta$ expression promoted barrier function [153]. By contrast, IL-25, expressed by mouse brain capillary endothelial cells, was shown to prevent inflammationinduced $\mathrm{BBB}$ disruption and down-regulation of $\mathrm{TJ}$ proteins (occludin, claudin-5, JAMs) through activation of the $n P K C-\varepsilon$ pathway [154]. Altogether, these observations strongly suggest that $\mathrm{nPKC}$-selective activation generally contributes to maintaining barrier integrity, whereas cPKC activation has the opposite effect, both in polarized epithelium and endothelium (Table 1).

Regarding aPKC isoforms ( $\lambda$ and $\zeta$ ), they have been shown to contribute to the establishment of epithelial cell polarity, via participation in the PCP complex together with Par-3 and Par-6 $[63,68,155]$. As mentioned above, the PCP complex is recruited to endothelial TJs by Par-3 binding to JAM proteins [64-66]. Over-expression of a dominant negative mutant of aPKC causes mislocalization of Par-3 and affects the biogenesis of the TJs in epithelial cells [67], suggesting that Par-3 is a substrate of aPKC and that its localization in epithelial cells is dependent upon its phosphorylation. In the same line, the VE-cadherin/CCM1 (a protein encoded by the CCM1 gene which is mutated in a large proportion of patients affected by cerebral cavernous malformation) complex controls aPKC- $\zeta$ activation and Par-3 localization during early steps of brain endothelial cell polarization [98]. The participation of this PCP complex to $\mathrm{TJ}$ integrity was further illustrated by the recent observation that meningococcal adhesion to human cerebral endothelial cells recruited Par-3, Par- 6 and aPKC- $\zeta$ under bacterial colonies and induced disruption of cell-cell junctions [156]. Surprisingly, a distinct Par-3/Par-6 complex, directly associated with VE-cadherin and lacking aPKC, has also been identified in endothelial cells [157]. Finally, although additional polarity complexes are known in epithelial cells (the apical Crumbs complex and the basolateral Scribble complex) where they also contribute to TJ formation and regulation, no similar observations have been reported, to our knowledge, in brain endothelial cells.

\section{BBB disruption mediated by Rho/ Rho kinase and MLCK activation}

The RhoA GTPase signaling pathway, activated by several membrane receptors, has been extensively documented in various cell types to induce actin cytoskeleton rearrangements involved in cell migration and proliferation. In brain endothelial cells, RhoA activation increased permeability, in response to inflammatory stimuli, through one of its major effectors Rho kinase (ROCK) [158,159]. Among these inflammatory stimuli, chemokines like MCP-1/CCL2, acting via their seven transmembranedomain receptors, are known to activate the RhoA/ROCK pathway in mouse brain endothelial cells, to induce occludin, claudin-5 and ZO-1 Ser/Thr-phosphorylation, followed by their delocalization from TJs, ultimately leading to increased barrier permeability [124,160]. Similarly, enhanced monocyte migration across human brain 
endothelial cells was observed in an HIV-1 encephalitis model $[123,161]$. Also, adhesion molecules like ICAM-1 and VCAM-1 were shown, in response to lymphocyte/ monocyte adhesion, to transduce signals in rat brain endothelial cell lines including activation of the RhoA/ ROCK pathway $[162,163]$ : activation of this pathway ultimately leads to enhanced lymphocyte migration, suggesting that this process may be involved in the massive infiltration of immune cells into the CNS observed in multiple sclerosis. It must be mentioned, however, that lymphocyte migration across the $\mathrm{BBB}$ may also happen via a transcellular pathway, leaving intact endothelial TJs [164].

Rearrangements of the actin cytoskeleton have long been recognized to be regulated, not only by the RhoA/ ROCK pathway, but also, often in a coordinated manner, by the myosin light chain kinase (MLCK): MLCK directly phosphorylates the myosin light chain, leading to actomyosin contraction and endothelial barrier disruption [165-167]. In the same line, inhibition of MLCK in bovine brain endothelial cells was more recently reported to prevent hypoxia-induced BBB disruption [127], whereas alcohol increased human brain endothelial cell permeability via activation of MLCK and phosphorylation of occludin and claudin-5 [125,126]. Recently, proinflammatory cytokines (IL1 $\beta$ and TNF $\alpha$ ), secreted by lymphocytes chronically infected by the HTLV-1 retrovirus, were reported to induce barrier disruption in the human brain endothelial cell line hCMEC/D3, associated with loss of occludin and ZO-1 through activation of the MLCK pathway [140].

In conclusion, as summarized in Table 1, inflammationor infection-induced actin cytoskeleton rearrangements in brain endothelial cells, mediated by the RhoA/ROCK and/or MLCK pathways, are associated with the phosphorylation, followed by delocalization or degradation of $\mathrm{TJ}$ proteins, and BBB disruption.

\section{BBB dysregulation by Tyr-phosphorylation of TJ proteins}

Early studies with cultured bovine brain endothelial cells and MDCK cells had pointed to Tyr-phosphorylation as a mechanism for increasing TJ permeability [131]. Accumulating evidence demonstrated that Tyr-phosphorylation of $\mathrm{TJ}$ proteins, as well as AJ proteins, was directly involved in BBB disruption, as observed in various pathological situations, although the identity of the Tyr-kinases involved often remained unknown. Unlike occludin Ser/Thr phosphorylation associated with barrier formation, as mentioned above, occludin Tyr-phosphorylation was reported to be associated with increased permeability of cultured rat brain endothelial cells exposed to glutamate, as a way to mimic cerebral ischemia [129] (Table 1). Like other pro-inflammatory cytokines, transforming growth factor (TGF)- $\beta 1$ is known to increase BBB permeability: as recently reported in bovine retinal and human brain endothelial cells, this effect was mediated by Tyrphosphorylation of both claudin-5 and VE-cadherin [130]. Vascular endothelial growth factor (VEGF), a major angiogenic factor, which is drastically enhanced in response to hypoxia, promotes Tyr-phosphorylation of $\mathrm{TJ}$ proteins (ZO-1, occludin) in mouse brain and retinal endothelial cells $[168,169]$ either directly via its membrane receptor tyrosine kinase VEGFR2 or via the activation of the cytosolic tyrosine kinase c-src $[128,170]$. VEGF-mediated Tyr-phosphorylation of TJ proteins in brain endothelial cells was often followed by their down-regulation and/or re-localization, leading to $\mathrm{TJ}$ destabilization and permeability increase [136-138,171].

\section{Alterations of expression and localization of TJ proteins}

Caveolae are specialized plasma membrane microdomains, abundantly found in endothelial cells where they mediate various biological events such as transcytosis, vascular permeability and angiogenesis [172,173]. They are enriched in the small membrane protein caveolin-1 which has been shown to recruit TJ proteins $[9,174]$. Caveolaemediated endocytosis induced by actin depolymerization was reported to evoke occludin internalization in MDCK cells [175]. Interestingly, exposure of cultured rat brain endothelial cells to the HIV-1 Tat protein was reported to increase TJ permeability, through alterations in expression and distribution of TJs proteins: occludin, claudin-5, ZO1, $\mathrm{ZO} 2[134,176]$. In the same line, the increase in TJ permeability observed in mouse brain endothelial cell response to the inflammatory cytokine CCL2 was recently shown to be associated with claudin-5 and occludin internalization in a caveolae-dependent manner [132]. Altogether these results strongly support the conclusion that alterations in expression and localization of TJ proteins, associated or not with their phosphorylation in response to various pathological stimuli, directly contribute to TJ disruption and BBB permeability increase (Table 1); in addition, they suggest a role of caveolin-1/caveolae in such TJ remodeling.

\section{Conclusion}

The brain endothelial TJ complex, which constitutes a key feature of the BBB, is now understood as a scaffolding and signaling platform in close interaction with the actin cytoskeleton and the AJ complex. It also appears as a dynamic complex, submitted to post-translational modifications in response to physiological and pathological stimuli. Indeed, perivascular cells of the NVU, notably astrocytes and pericytes, secrete multiple growth factors and morphogens that contribute to TJ formation and integrity. Conversely, various pathological situations associated with the presence of inflammatory cytokines, reactive oxygen 
species or pathogens, lead to TJ disruption following phosphorylation and/or internalization of $\mathrm{TJ}$ proteins.

Although our understanding of $\mathrm{TJ}$ architecture and function has significantly increased over the last ten years, a number of issues will have to be addressed in the next future, in particular taking advantage of new and/or global analysis technologies. For example, superresolution light microscopy (time-lapse stimulated emission depletion (STED) imaging) recently appeared as a very powerful approach to unravel synapse assembly and plasticity [177]; in the same line, super-resolution microscopy of TJs (with a resolution down to $50-80 \mathrm{~nm}$ ) of cerebral microvessels in brain slices should provide a more accurate understanding of $\mathrm{TJ}$ organization and dynamics. Also, thanks to the availability of validated $\mathrm{BBB}$ in vitro models, identification by mass spectrometry (MS/MS analysis) of the secreted proteins (so-called 'secretome') from brain endothelial co-cultures with astrocytes or pericytes may unravel new paracrine signaling pathways in the NVU which contribute to the stabilization of TJs at the BBB; in addition, similar analyses in the presence of inflammatory agents or pathogens [178] may highlight unsuspected mechanisms of TJ disruption. This approach will complement quantitative targeted absolute proteomics (also known as selected reaction monitoring (SRM)), an emerging approach to quantify membrane proteins [179]. This technology will also greatly benefit the field, allowing absolute quantification of $\mathrm{TJ}$ proteins in physiological and various pharmacological situations, as recently proposed [180]. The treatment of neurological diseases is currently hampered by difficulties encountered in delivering therapeutic compounds to the brain, across the BBB. Because previous drug delivery strategies based on transcellular transport machinery have shown limited efficacy so far, it is tempting to propose that transient modulation of $\mathrm{TJ}$ at the $\mathrm{BBB}$, using in vitro models of the BBB and in vivo models of human pathologies, may constitute an alternative approach for drug delivery to the brain. Clearly, this field will benefit greatly from an in-depth understanding of TJ architecture and functional regulatory mechanisms.

\footnotetext{
Abbreviations

AJ: Adherens junction; BBB: Blood brain barrier; CNS: Central nervous system; ECL: Extracellular loop; Fz: Frizzled; HUVEC: Human umbilical vein endothelial cell; IL: Interleukin; JAM: Junctional adhesion molecule; MAGUK: Membrane associated guanylate kinase; MLCK: Myosin light chain kinase; NVU: Neurovascular unit; PCP: Planar cell polarity; PKC: Protein kinase C; Ptch1: Patched-1; ROCK: Rho kinase; Shh: Sonic hedgehog;

Smo: Smoothened; TAMP: Tight junction-associated marvel proteins; TGF: Transforming growth factor; TJ: Tight junction; VEGF: Vascular endothelial growth factor; ZO: Zonula occludens.
}

\section{Competing interests}

The authors declare no conflict of interest.

\section{Authors' contributions}

$A C L$ and $C A$ : were responsible for the collection of data and references, and for the drafting of the document. FG and KG were involved in the collection of data and drafting of the document. POC was responsible for the drafting and editing of the document, and for the discussion of the data. All authors read and approved the final manuscript.

\section{Author details}

${ }^{1}$ INSERM U1016, Institut Cochin, Paris, France. ${ }^{2}$ CNRS, UMR 8104, Paris, France. ${ }^{3}$ Université Paris Descartes, Sorbonne Paris Cité, Paris, France.

Received: 3 July 2012 Accepted: 21 October 2012

Published: 9 November 2012

\section{References}

1. Abbott NJ, Patabendige AA, Dolman DE, Yusof SR, Begley DJ: Structure and function of the blood-brain barrier. Neurobiol Dis 2010, 37:13-25.

2. Begley DJ, Brightman MW: Structural and functional aspects of the blood-brain barrier. Prog Drug Res 2003, 61:39-78.

3. Wolburg H, Noell S, Mack A, Wolburg-Buchholz K, Fallier-Becker P: Brain endothelial cells and the glio-vascular complex. Cell Tissue Res 2009, 335:75-96.

4. Tsukita S, Furuse M, Itoh M: Multifunctional strands in tight junctions. Nat Rev Mol Cell Biol 2001, 2:285-293.

5. Cereijido M, Valdes J, Shoshani L, Contreras RG: Role of tight junctions in establishing and maintaining cell polarity. Annu Rev Physiol 1998, 60:161-177.

6. Gumbiner BM: Breaking through the tight junction barrier. J Cell Biol 1993, 123:1631-1633.

7. Schneeberger EE, Lynch RD: Structure, function, and regulation of cellular tight junctions. Am J Physiol 1992, 262:L647-661.

8. Vorbrodt AW, Dobrogowska DH: Molecular anatomy of intercellular junctions in brain endothelial and epithelial barriers: electron microscopist's view. Brain Res Brain Res Rev 2003, 42:221-242.

9. Luissint AC, Federici C, Guillonneau F, Chretien F, Camoin L, Glacial F, Ganeshamoorthy K, Couraud PO: Guanine nucleotide-binding protein Galphai2: a new partner of claudin-5 that regulates tight junction integrity in human brain endothelial cells. J Cereb Blood Flow Metab 2012, 32:860-873.

10. Aijaz S, Balda MS, Matter K: Tight junctions: molecular architecture and function. Int Rev Cytol 2006, 248:261-298.

11. Redzic Z: Molecular biology of the blood-brain and the bloodcerebrospinal fluid barriers: similarities and differences. Fluids Barriers CNS 2011, 8:3.

12. Ando-Akatsuka $Y$, Saitou M, Hirase T, Kishi M, Sakakibara A, Itoh M, Yonemura S, Furuse M, Tsukita S: Interspecies diversity of the occludin sequence: CDNA cloning of human, mouse, dog, and rat-kangaroo homologues. J Cell Biol 1996, 133:43-47.

13. Furuse M, Hirase T, Itoh M, Nagafuchi A, Yonemura S, Tsukita S: Occludin: a novel integral membrane protein localizing at tight junctions. J Cell Biol 1993, 123:1777-1788.

14. Balda MS, Whitney JA, Flores C, Gonzalez S, Cereijido M, Matter K: Functional dissociation of paracellular permeability and transepithelial electrical resistance and disruption of the apical-basolateral intramembrane diffusion barrier by expression of a mutant tight junction membrane protein. J Cell Biol 1996, 134:1031-1049.

15. Ikenouchi J, Furuse M, Furuse K, Sasaki H, Tsukita S: Tricellulin constitutes a novel barrier at tricellular contacts of epithelial cells. J Cell Biol 2005, 171:939-945.

16. Raleigh DR, Marchiando AM, Zhang Y, Shen L, Sasaki H, Wang Y, Long M, Turner JR: Tight junction-associated MARVEL proteins marveld3, tricellulin, and occludin have distinct but overlapping functions. $\mathrm{Mol} \mathrm{BiO}$ Cell 2010, 21:1200-1213.

17. Steed E, Rodrigues NT, Balda MS, Matter K: Identification of MarvelD3 as a tight junction-associated transmembrane protein of the occludin family. BMC Cell Biol 2009, 10:95.

18. Yaffe Y, Shepshelovitch J, Nevo-Yassaf I, Yeheskel A, Shmerling H, Kwiatek JM, Gaus K, Pasmanik-Chor M, Hirschberg K: The MARVEL transmembrane motif of occludin mediates oligomerization and targeting to the basolateral surface in epithelia. J Cell Sci 2012, 125:3545-3556. 
19. Blasig IE, Winkler L, Lassowski B, Mueller SL, Zuleger N, Krause E, Krause G, Gast K, Kolbe M, Piontek J: On the self-association potential of transmembrane tight junction proteins. Cell Mol Life Sci 2006, 63:505-514.

20. Walter JK, Castro V, Voss M, Gast K, Rueckert C, Piontek J, Blasig IE: Redoxsensitivity of the dimerization of occludin. Cell Mol Life Sci 2009, 66:3655-3662.

21. Walter JK, Rueckert C, Voss M, Mueller SL, Piontek J, Gast K, Blasig IE: The oligomerization of the coiled coil-domain of occludin is redox sensitive. Ann N Y Acad Sci 2009, 1165:19-27.

22. Lochhead JJ, McCaffrey G, Quigley CE, Finch J, DeMarco KM, Nametz N, Davis TP: Oxidative stress increases blood-brain barrier permeability and induces alterations in occludin during hypoxia-reoxygenation. J Cereb Blood Flow Metab 2010, 30:1625-1636.

23. Lochhead JJ, McCaffrey G, Sanchez-Covarrubias L, Finch JD, Demarco KM, Quigley CE, Davis TP, Ronaldson PT: Tempol modulates changes in xenobiotic permeability and occludin oligomeric assemblies at the blood-brain barrier during inflammatory pain. Am J Physiol Heart Circ Physiol 2012, 302:H582-593.

24. McCaffrey G, Seelbach MJ, Staatz WD, Nametz N, Quigley C, Campos CR, Brooks TA, Davis TP: Occludin oligomeric assembly at tight junctions of the blood-brain barrier is disrupted by peripheral inflammatory hyperalgesia. J Neurochem 2008, 106:2395-2409.

25. Blasig IE, Bellmann C, Cording J, Del Vecchio G, Zwanziger D, Huber O, Haseloff RF: Occludin protein family: oxidative stress and reducing conditions. Antioxid Redox Signal 2011, 15:1195-1219.

26. Medina R, Rahner C, Mitic LL, Anderson JM, Van Itallie CM: Occludin localization at the tight junction requires the second extracellular loop. J Membr Biol 2000, 178:235-247.

27. Wong V, Gumbiner BM: A synthetic peptide corresponding to the extracellular domain of occludin perturbs the tight junction permeability barrier. J Cell Biol 1997, 136:399-409.

28. Tavelin S, Hashimoto K, Malkinson J, Lazorova L, Toth I, Artursson P: A new principle for tight junction modulation based on occludin peptides. Mol Pharmacol 2003, 64:1530-1540.

29. Everett RS, Vanhook MK, Barozzi N, Toth I, Johnson LG: Specific modulation of airway epithelial tight junctions by apical application of an occludin peptide. Mol Pharmacol 2006, 69:492-500.

30. Furuse M, Fujimoto K, Sato N, Hirase T, Tsukita S: Overexpression of occludin, a tight junction-associated integral membrane protein, induces the formation of intracellular multilamellar bodies bearing tight junction-like structures. J Cell Sci 1996, 109(Pt 2):429-435.

31. McCarthy KM, Skare IB, Stankewich MC, Furuse M, Tsukita S, Rogers RA, Lynch RD, Schneeberger EE: Occludin is a functional component of the tight junction. J Cell Sci 1996, 109(Pt 9):2287-2298.

32. Schubert-Unkmeir A, Konrad C, Slanina H, Czapek F, Hebling S, Frosch M: Neisseria meningitidis induces brain microvascular endothelial cell detachment from the matrix and cleavage of occludin: a role for MMP-8. PLOS Pathog 2010, 6:e1000874.

33. Xu R, Feng $X$, Xie $X$, Zhang J, Wu D, Xu L: HIV-1 Tat protein increases the permeability of brain endothelial cells by both inhibiting occludin expression and cleaving occludin via matrix metalloproteinase-9. Brain Res 2012, 1436:13-19.

34. Moroi S, Saitou M, Fujimoto K, Sakakibara A, Furuse M, Yoshida O, Tsukita S: Occludin is concentrated at tight junctions of mouse/rat but not human/ guinea pig Sertoli cells in testes. Am J Physio/ 1998, 274:C1708-1717.

35. Saitou M, Fujimoto K, Doi Y, Itoh M, Fujimoto T, Furuse M, Takano H, Noda T, Tsukita S: Occludin-deficient embryonic stem cells can differentiate into polarized epithelial cells bearing tight junctions. J Cell Biol 1998, 141:397-408.

36. Saitou M, Furuse M, Sasaki H, Schulzke JD, Fromm M, Takano H, Noda T, Tsukita S: Complex phenotype of mice lacking occludin, a component of tight junction strands. Mol Biol Cell 2000, 11:4131-4142.

37. Schulzke JD, Gitter AH, Mankertz J, Spiegel S, Seidler U, Amasheh S, Saitou M, Tsukita S, Fromm M: Epithelial transport and barrier function in occludin-deficient mice. Biochim Biophys Acta 2005, 1669:34-42.

38. Furuse M, Sasaki H, Tsukita S: Manner of interaction of heterogeneous claudin species within and between tight junction strands. J Cell Biol 1999, 147:891-903.

39. Mineta K, Yamamoto Y, Yamazaki Y, Tanaka H, Tada Y, Saito K, Tamura A, Igarashi M, Endo T, Takeuchi K, Tsukita S: Predicted expansion of the claudin multigene family. FEBS Lett 2011, 585:606-612.
40. Morita K, Furuse M, Fujimoto K, Tsukita S: Claudin multigene family encoding four-transmembrane domain protein components of tight junction strands. Proc Natl Acad Sci USA 1999, 96:511-516.

41. Wolburg H, Wolburg-Buchholz K, Kraus J, Rascher-Eggstein G, Liebner S, Hamm S, Duffner F, Grote EH, Risau W, Engelhardt B: Localization of claudin-3 in tight junctions of the blood-brain barrier is selectively lost during experimental autoimmune encephalomyelitis and human glioblastoma multiforme. Acta Neuropathol 2003, 105:586-592.

42. Morita K, Sasaki H, Furuse M, Tsukita S: Endothelial claudin: claudin-5/TMVCF constitutes tight junction strands in endothelial cells. J Cell Biol 1999, 147:185-194.

43. Nitta T, Hata M, Gotoh S, Seo Y, Sasaki H, Hashimoto N, Furuse M, Tsukita S: Size-selective loosening of the blood-brain barrier in claudin-5-deficient mice. J Cell Biol 2003, 161:653-660.

44. Ohtsuki S, Sato S, Yamaguchi H, Kamoi M, Asashima T, Terasaki T: Exogenous expression of claudin-5 induces barrier properties in cultured rat brain capillary endothelial cells. J Cell Physiol 2007, 210:81-86.

45. Piehl C, Piontek J, Cording J, Wolburg H, Blasig IE: Participation of the second extracellular loop of claudin-5 in paracellular tightening against ions, small and large molecules. Cell Mol Life Sci 2010, 67:2131-2140.

46. Piontek J, Winkler L, Wolburg H, Muller SL, Zuleger N, Piehl C, Wiesner B, Krause G, Blasig IE: Formation of tight junction: determinants of homophilic interaction between classic claudins. FASEB J 2008, 22:146-158

47. Zhang J, Piontek J, Wolburg H, Piehl C, Liss M, Otten C, Christ A, Willnow TE, Blasig IE, Abdelilah-Seyfried S: Establishment of a neuroepithelial barrier by Claudin5a is essential for zebrafish brain ventricular lumen expansion. Proc Natl Acad Sci USA 2010, 107:1425-1430.

48. Coyne CB, Gambling TM, Boucher RC, Carson JL, Johnson LG: Role of claudin interactions in airway tight junctional permeability. Am J Physiol Lung Cell Mol Physiol 2003, 285:L1166-1178.

49. Piontek J, Fritzsche S, Cording J, Richter S, Hartwig J, Walter M, Yu D, Turner JR, Gehring C, Rahn HP, et al: Elucidating the principles of the molecular organization of heteropolymeric tight junction strands. Cell Mol Life Sci 2011, 68:3903-3918.

50. Bazzoni G: Pathobiology of junctional adhesion molecules. Antioxid Redox Signal 2011, 15:1221-1234.

51. Ebnet K, Suzuki A, Ohno S, Vestweber D: Junctional adhesion molecules (JAMs): more molecules with dual functions? J Cell Sci 2004, 117:19-29.

52. Stevenson BR, Siliciano JD, Mooseker MS, Goodenough DA: Identification of ZO-1: a high molecular weight polypeptide associated with the tight junction (zonula occludens) in a variety of epithelia. J Cell Biol 1986, 103:755-766.

53. Gumbiner B, Lowenkopf T, Apatira D: Identification of a 160-kDa polypeptide that binds to the tight junction protein ZO-1. Proc Natl Acad SCi USA 1991, 88:3460-3464.

54. Haskins J, Gu L, Wittchen ES, Hibbard J, Stevenson BR: ZO-3, a novel member of the MAGUK protein family found at the tight junction, interacts with ZO-1 and occludin. J Cell Biol 1998, 141:199-208.

55. Fanning AS, Jameson BJ, Jesaitis LA, Anderson JM: The tight junction protein ZO-1 establishes a link between the transmembrane protein occludin and the actin cytoskeleton. J Biol Chem 1998, 273:29745-29753.

56. Itoh M, Morita K, Tsukita S: Characterization of ZO-2 as a MAGUK family member associated with tight as well as adherens junctions with a binding affinity to occludin and alpha catenin. J Biol Chem 1999, 274:5981-5986.

57. Itoh M, Furuse M, Morita K, Kubota K, Saitou M, Tsukita S: Direct binding of three tight junction-associated MAGUKs, ZO-1, ZO-2, and ZO-3, with the $\mathrm{COOH}$ termini of claudins. J Cell Biol 1999, 147:1351-1363.

58. Bazzoni G, Martinez-Estrada OM, Orsenigo F, Cordenonsi M, Citi S, Dejana E: Interaction of junctional adhesion molecule with the tight junction components ZO-1, cingulin, and occludin. J Biol Chem 2000, 275:20520-20526.

59. Furuse $M$, Itoh M, Hirase T, Nagafuchi A, Yonemura S, Tsukita S: Direct association of occludin with ZO-1 and its possible involvement in the localization of occludin at tight junctions. J Cell Biol 1994, 127:1617-1626.

60. Umeda K, Ikenouchi J, Katahira-Tayama S, Furuse K, Sasaki H, Nakayama M, Matsui T, Tsukita S, Furuse M: ZO-1 and ZO-2 independently determine where claudins are polymerized in tight-junction strand formation. Cell 2006, 126:741-754. 
61. Nusrat A, Brown GT, Tom J, Drake A, Bui TT, Quan C, Mrsny RJ: Multiple protein interactions involving proposed extracellular loop domains of the tight junction protein occludin. Mol Biol Cell 2005, 16:1725-1734.

62. Fanning AS, Ma TY, Anderson JM: Isolation and functional characterization of the actin binding region in the tight junction protein ZO-1. FASEB J 2002, 16:1835-1837.

63. Izumi $Y$, Hirose T, Tamai $Y$, Hirai $S$, Nagashima $Y$, Fujimoto T, Tabuse $Y$, Kemphues KJ, Ohno S: An atypical PKC directly associates and colocalizes at the epithelial tight junction with ASIP, a mammalian homologue of caenorhabditis elegans polarity protein PAR-3. J Cell Biol 1998, 143:95-106.

64. Ebnet K, Aurrand-Lions M, Kuhn A, Kiefer F, Butz S, Zander K, Meyer zu Brickwedde MK, Suzuki A, Imhof BA, Vestweber D: The junctional adhesion molecule (JAM) family members JAM-2 and JAM-3 associate with the cell polarity protein PAR-3: a possible role for JAMs in endothelial cell polarity. J Cell Sci 2003, 116:3879-3891.

65. Ebnet K, Suzuki A, Horikoshi Y, Hirose T, Meyer Zu Brickwedde MK, Ohno S, Vestweber D: The cell polarity protein ASIP/PAR-3 directly associates with junctional adhesion molecule (JAM). EMBO J 2001, 20:3738-3748.

66. Itoh M, Sasaki H, Furuse M, Ozaki H, Kita T, Tsukita S: Junctional adhesion molecule (JAM) binds to PAR-3: a possible mechanism for the recruitment of PAR-3 to tight junctions. J Cell Biol 2001, 154:491-497.

67. Suzuki A, Yamanaka T, Hirose T, Manabe N, Mizuno K, Shimizu M, Akimoto K, Izumi Y, Ohnishi T, Ohno S: Atypical protein kinase $C$ is involved in the evolutionarily conserved par protein complex and plays a critical role in establishing epithelia-specific junctional structures. J Cell Biol 2001, 152:1183-1196.

68. Joberty G, Petersen C, Gao L, Macara IG: The cell-polarity protein Par6 links Par3 and atypical protein kinase C to Cdc42. Nat Cell Biol 2000, 2:531-539.

69. Lin D, Edwards AS, Fawcett JP, Mbamalu G, Scott JD, Pawson T: A mammalian PAR-3-PAR-6 complex implicated in Cdc42/Rac1 and aPKC signalling and cell polarity. Nat Cell Biol 2000, 2:540-547.

70. Daneman R, Zhou L, Agalliu D, Cahoy JD, Kaushal A, Barres BA: The mouse blood-brain barrier transcriptome: a new resource for understanding the development and function of brain endothelial cells. PLoS One 2010, 5:e13741.

71. Denker BM, Saha C, Khawaja S, Nigam SK: Involvement of a heterotrimeric $\mathrm{G}$ protein alpha subunit in tight junction biogenesis. J Biol Chem 1996, 271:25750-25753.

72. Saha C, Nigam SK, Denker BM: Involvement of Galphai2 in the maintenance and biogenesis of epithelial cell tight junctions. J Biol Chem 1998, 273:21629-21633.

73. Fabian G, Szabo CA, Bozo B, Greenwood J, Adamson P, Deli MA, Joo F, Krizbai IA, Szucs M: Expression of G-protein subtypes in cultured cerebral endothelial cells. Neurochem Int 1998, 33:179-185.

74. Adamson P, Wilbourn B, Etienne-Manneville S, Calder V, Beraud E, Milligan G, Couraud PO, Greenwood J: Lymphocyte trafficking through the blood-brain barrier is dependent on endothelial cell heterotrimeric G-protein signaling. FASEB J 2002, 16:1185-1194.

75. Pero RS, Borchers MT, Spicher K, Ochkur SI, Sikora L, Rao SP, Abdala-Valencia $\mathrm{H}, \mathrm{O}^{\prime}$ Neill KR, Shen H, McGarry MP, et al: Galphai2-mediated signaling events in the endothelium are involved in controlling leukocyte extravasation. Proc Natl Acad Sci USA 2007, 104:4371-4376.

76. Abbott NJ, Ronnback L, Hansson E: Astrocyte-endothelial interactions at the blood-brain barrier. Nat Rev Neurosci 2006, 7:41-53.

77. Janzer RC, Raff MC: Astrocytes induce blood-brain barrier properties in endothelial cells. Nature 1987, 325:253-257.

78. Bonkowski D, Katyshev V, Balabanov RD, Borisov A, Dore-Duffy P: The CNS microvascular pericyte: pericyte-astrocyte crosstalk in the regulation of tissue survival. Fluids Barriers CNS 2011, 8:8.

79. Sa-Pereira I, Brites D, Brito MA: Neurovascular unit: a focus on pericytes. Mol Neurobiol 2012, 45:327-347.

80. Winkler EA, Bell RD, Zlokovic BV: Pericyte-specific expression of PDGF beta receptor in mouse models with normal and deficient PDGF beta receptor signaling. Mol Neurodegener 2010, 5:32.

81. Arthur FE, Shivers RR, Bowman PD: Astrocyte-mediated induction of tight junctions in brain capillary endothelium: an efficient in vitro model. Brain Res 1987, 433:155-159.

82. Colgan OC, Collins NT, Ferguson G, Murphy RP, Birney YA, Cahill PA, Cummins PM: Influence of basolateral condition on the regulation of brain microvascular endothelial tight junction properties and barrier function. Brain Res 2008, 1193:84-92.

83. Lee SW, Kim WJ, Choi YK, Song HS, Son MJ, Gelman IH, Kim YJ, Kim KW: SSeCKS regulates angiogenesis and tight junction formation in blood-brain barrier. Nat Med 2003, 9:900-906

84. Neuhaus J, Risau W, Wolburg H: Induction of blood-brain barrier characteristics in bovine brain endothelial cells by rat astroglial cells in transfilter coculture. Ann N Y Acad Sci 1991, 633:578-580.

85. Rubin LL, Hall DE, Porter S, Barbu K, Cannon C, Horner HC, Janatpour M, Liaw CW, Manning K, Morales J, et al: A cell culture model of the blood-brain barrier. J Cell Biol 1991, 115:1725-1735.

86. Tao-Cheng JH, Nagy Z, Brightman MW: Tight junctions of brain endothelium in vitro are enhanced by astroglia. J Neurosci 1987 7:3293-3299.

87. Wolburg H, Neuhaus J, Kniesel U, Krauss B, Schmid EM, Ocalan M, Farrell C, Risau W: Modulation of tight junction structure in blood-brain barrier endothelial cells. Effects of tissue culture, second messengers and cocultured astrocytes. J Cell Sci 1994, 107(Pt 5):1347-1357.

88. Hori S, Ohtsuki S, Hosoya K, Nakashima E, Terasaki T: A pericyte-derived angiopoietin-1 multimeric complex induces occludin gene expression in brain capillary endothelial cells through Tie-2 activation in vitro. J Neurochem 2004, 89:503-513.

89. Daneman $R$, Zhou $L$, Kebede AA, Barres BA: Pericytes are required for blood-brain barrier integrity during embryogenesis. Nature 2010, 468:562-566.

90. Armulik A, Genove G, Mae M, Nisancioglu MH, Wallgard E, Niaudet C, He L, Norlin J, Lindblom P, Strittmatter K, et al: Pericytes regulate the blood-brain barrier. Nature 2010, 468:557-561.

91. Dohgu S, Takata F, Yamauchi A, Nakagawa S, Egawa T, Naito M, Tsuruo T, Sawada Y, Niwa M, Kataoka Y: Brain pericytes contribute to the induction and up-regulation of blood-brain barrier functions through transforming growth factor-beta production. Brain Res 2005, 1038:208-215.

92. Liebner S, Czupalla CJ, Wolburg H: Current concepts of blood-brain barrier development. Int J Dev Biol 2011, 55:467-476.

93. Osada T, Gu YH, Kanazawa M, Tsubota Y, Hawkins BT, Spatz M, Milner R, del Zoppo GJ: Interendothelial claudin-5 expression depends on cerebral endothelial cell-matrix adhesion by beta(1)-integrins. J Cereb Blood Flow Metab 2011, 31:1972-1985.

94. Zovein AC, Luque A, Turlo KA, Hofmann JJ, Yee KM, Becker MS, Fassler R, Mellman I, Lane TF, Iruela-Arispe ML: Beta1 integrin establishes endothelial cell polarity and arteriolar lumen formation via a Par3-dependent mechanism. Dev Cell 2010, 18:39-51.

95. Alvarez JI, Dodelet-Devillers A, Kebir H, Ifergan I, Fabre PJ, Terouz S, Sabbagh M, Wosik K, Bourbonniere L, Bernard M, et al: The Hedgehog pathway promotes blood-brain barrier integrity and CNS immune quiescence. Science 2011, 334:1727-1731.

96. Liebner S, Corada M, Bangsow T, Babbage J, Taddei A, Czupalla CJ, Reis M, Felici A, Wolburg H, Fruttiger M, et al: Wnt/beta-catenin signaling controls development of the blood-brain barrier. J Cell Biol 2008, 183:409-417.

97. Taddei A, Giampietro C, Conti A, Orsenigo F, Breviario F, Pirazzoli V, Potente M, Daly C, Dimmeler S, Dejana E: Endothelial adherens junctions control tight junctions by VE-cadherin-mediated upregulation of claudin-5. Nat Cell Biol 2008, 10:923-934.

98. Lampugnani MG, Orsenigo F, Rudini N, Maddaluno L, Boulday G, Chapon F, Dejana E: CCM1 regulates vascular-lumen organization by inducing endothelial polarity. J Cell Sci 2010, 123:1073-1080.

99. Chien AJ, Conrad WH, Moon RT: A Wnt survival guide: from flies to human disease. J Invest Dermatol 2009, 129:1614-1627.

100. Stenman JM, Rajagopal J, Carroll TJ, Ishibashi M, McMahon J, McMahon AP: Canonical Wnt signaling regulates organ-specific assembly and differentiation of CNS vasculature. Science 2008, 322:1247-1250.

101. Ye X, Wang Y, Cahill H, Yu M, Badea TC, Smallwood PM, Peachey NS, Nathans J: Norrin, frizzled-4, and Lrp5 signaling in endothelial cells controls a genetic program for retinal vascularization. Cell 2009, 139:285-298.

102. Daneman R, Agalliu D, Zhou L, Kuhnert F, Kuo CJ, Barres BA Wnt/beta-catenin signaling is required for CNS, but not non-CNS, angiogenesis. Proc Natl Acad Sci USA 2009, 106:641-646.

103. Paolinelli R, Corada M, Orsenigo F, Dejana E: The molecular basis of the blood brain barrier differentiation and maintenance. Is it still a mystery? Pharmacol Res 2011, 63:165-171. 
104. Wu C, Ivars F, Anderson P, Hallmann R, Vestweber D, Nilsson P, Robenek $H$ Tryggvason K, Song J, Korpos E, et al: Endothelial basement membrane laminin alpha5 selectively inhibits T lymphocyte extravasation into the brain. Nat Med 2009, 15:519-527.

105. Barber AJ, Lieth E: Agrin accumulates in the brain microvascular basal lamina during development of the blood-brain barrier. Dev Dyn 1997, 208:62-74.

106. Rascher G, Fischmann A, Kroger S, Duffner F, Grote EH, Wolburg H: Extracellular matrix and the blood-brain barrier in glioblastoma multiforme: spatial segregation of tenascin and agrin. Acta Neuropathol 2002, 104:85-91.

107. Gavard J: Breaking the VE-cadherin bonds. FEBS Lett 2009, 583:1-6.

108. Dejana E, Giampietro C: Vascular endothelial-cadherin and vascular stability. Curr Opin Hematol 2012, 19:218-223.

109. Harris ES, Nelson WJ: VE-cadherin: at the front, center, and sides of endothelial cell organization and function. Curr Opin Cell Biol 2010, 22:651-658.

110. Stanness KA, Westrum LE, Fornaciari E, Mascagni P, Nelson JA, Stenglein SG, Myers T, Janigro D: Morphological and functional characterization of an in vitro blood-brain barrier model. Brain Res 1997, 771:329-342.

111. Mairey E, Genovesio A, Donnadieu E, Bernard C, Jaubert F, Pinard E, Seylaz J, Olivo-Marin JC, Nassif X, Dumenil G: Cerebral microcirculation shear stress levels determine Neisseria meningitidis attachment sites along the blood-brain barrier. J Exp Med 2006, 203:1939-1950.

112. Santaguida S, Janigro D, Hossain M, Oby E, Rapp E, Cucullo L: Side by side comparison between dynamic versus static models of blood-brain barrier in vitro: a permeability study. Brain Res 2006, 1109:1-13.

113. Colgan OC, Ferguson G, Collins NT, Murphy RP, Meade G, Cahill PA, Cummins PM: Regulation of bovine brain microvascular endothelial tight junction assembly and barrier function by laminar shear stress. Am J Physiol Heart Circ Physiol 2007, 292:H3190-3197.

114. Krizanac-Bengez L, Mayberg MR, Cunningham E, Hossain M, Ponnampalam $\mathrm{S}$, Parkinson FE, Janigro D: Loss of shear stress induces leukocyte-mediated cytokine release and blood-brain barrier failure in dynamic in vitro blood-brain barrier model. J Cell Physiol 2006, 206:68-77.

115. Siddharthan V, Kim YV, Liu S, Kim KS: Human astrocytes/astrocyteconditioned medium and shear stress enhance the barrier properties of human brain microvascular endothelial cells. Brain Res 2007, 1147:39-50.

116. Cucullo L, Hossain M, Puvenna V, Marchi N, Janigro D: The role of shear stress in blood-brain barrier endothelial physiology. BMC Neurosci 2011, 12:40.

117. Walsh TG, Murphy RP, Fitzpatrick P, Rochfort KD, Guinan AF, Murphy A, Cummins PM: Stabilization of brain microvascular endothelial barrier function by shear stress involves VE-cadherin signaling leading to modulation of pTyr-occludin levels. J Cell Physiol 2011, 226:3053-3063.

118. Cummins PM: Occludin: one protein, many forms. Mol Cell Biol 2012, 32:242-250.

119. Dorfel MJ, Huber O: Modulation of tight junction structure and function by kinases and phosphatases targeting occludin. J Biomed Biotechnol 2012, 2012:807356.

120. Soma T, Chiba H, Kato-Mori Y, Wada T, Yamashita T, Kojima T, Sawada N: $\operatorname{Thr}(207)$ of claudin-5 is involved in size-selective loosening of the endothelial barrier by cyclic AMP. Exp Cell Res 2004 300:202-212.

121. Willis CL, Meske DS, Davis TP: Protein kinase $\mathrm{C}$ activation modulates reversible increase in cortical blood-brain barrier permeability and tight junction protein expression during hypoxia and posthypoxic reoxygenation. J Cereb Blood Flow Metab 2010, 30:1847-1859.

122. Kanmogne GD, Schall K, Leibhart J, Knipe B, Gendelman HE, Persidsky Y: HIV-1 gp120 compromises blood-brain barrier integrity and enhances monocyte migration across blood-brain barrier: implication for viral neuropathogenesis. J Cereb Blood Flow Metab 2007, 27:123-134.

123. Yamamoto M, Ramirez SH, Sato S, Kiyota T, Cerny RL, Kaibuchi K, Persidsky Y, Ikezu T: Phosphorylation of claudin-5 and occludin by rho kinase in brain endothelial cells. Am J Pathol 2008, 172:521-533.

124. Stamatovic SM, Dimitrijevic OB, Keep RF, Andjelkovic AV: Protein kinase Calpha-RhoA cross-talk in CCL2-induced alterations in brain endothelial permeability. J Biol Chem 2006, 281:8379-8388.

125. Haorah J, Knipe B, Leibhart J, Ghorpade A, Persidsky Y: Alcohol-induced oxidative stress in brain endothelial cells causes blood-brain barrier dysfunction. J Leukoc Biol 2005, 78:1223-1232.
126. Haorah J, Heilman D, Knipe B, Chrastil J, Leibhart J, Ghorpade A, Miller DW, Persidsky Y: Ethanol-induced activation of myosin light chain kinase leads to dysfunction of tight junctions and blood-brain barrier compromise. Alcohol Clin Exp Res 2005, 29:999-1009.

127. Kuhlmann CR, Tamaki R, Gamerdinger M, Lessmann V, Behl C, Kempski OS, Luhmann $\mathrm{HJ}$ : Inhibition of the myosin light chain kinase prevents hypoxia-induced blood-brain barrier disruption. J Neurochem 2007, 102:501-507.

128. Takenaga Y, Takagi N, Murotomi K, Tanonaka K, Takeo S: Inhibition of Src activity decreases tyrosine phosphorylation of occludin in brain capillaries and attenuates increase in permeability of the blood-brain barrier after transient focal cerebral ischemia. J Cereb Blood Flow Metab 2009, 29:1099-1108.

129. Andras IE, Deli MA, Veszelka S, Hayashi K, Hennig B, Toborek M: The NMDA and AMPA/KA receptors are involved in glutamate-induced alterations of occludin expression and phosphorylation in brain endothelial cells. J Cereb Blood Flow Metab 2007, 27:1431-1443.

130. Shen W, Li S, Chung SH, Zhu L, Stayt J, Su T, Couraud PO, Romero IA, Weksler B, Gillies MC: Tyrosine phosphorylation of VE-cadherin and claudin-5 is associated with TGF-beta1-induced permeability of centrally derived vascular endothelium. Eur J Cell Biol 2011, 90:323-332.

131. Staddon JM, Herrenknecht K, Smales C, Rubin LL: Evidence that tyrosine phosphorylation may increase tight junction permeability. J Cell Sci 1995, 108(Pt 2):609-619.

132. Stamatovic SM, Keep RF, Wang MM, Jankovic I, Andjelkovic AV: Caveolaemediated internalization of occludin and claudin-5 during CCL2-induced tight junction remodeling in brain endothelial cells. J Biol Chem 2009, 284:19053-19066.

133. Tai LM, Holloway KA, Male DK, Loughlin AJ, Romero IA: Amyloid-betainduced occludin down-regulation and increased permeability in human brain endothelial cells is mediated by MAPK activation. $J$ Cell Mol Med 2010, 14:1101-1112.

134. Andras IE, Pu H, Tian J, Deli MA, Nath A, Hennig B, Toborek M: Signaling mechanisms of HIV-1 Tat-induced alterations of claudin-5 expression in brain endothelial cells. J Cereb Blood Flow Metab 2005, 25:1159-1170.

135. Fischer S, Wiesnet M, Marti HH, Renz D, Schaper W: Simultaneous activation of several second messengers in hypoxia-induced hyperpermeability of brain derived endothelial cells. J Cell Physiol 2004, 198:359-369.

136. Mark KS, Davis TP: Cerebral microvascular changes in permeability and tight junctions induced by hypoxia-reoxygenation. Am J Physiol Heart Circ Physiol 2002, 282:H1485-1494.

137. Koto T, Takubo K, Ishida S, Shinoda H, Inoue M, Tsubota K, Okada Y, Ikeda E: Hypoxia disrupts the barrier function of neural blood vessels through changes in the expression of claudin-5 in endothelial cells. Am J Pathol 2007, 170:1389-1397.

138. Argaw AT, Gurfein BT, Zhang Y, Zameer A, John GR: VEGF-mediated disruption of endothelial CLN-5 promotes blood-brain barrier breakdown. Proc Natl Acad Sci USA 2009, 106:1977-1982

139. Jiao $H$, Wang $Z$, Liu $Y$, Wang $P$, Xue $Y$ : Specific role of tight junction proteins claudin-5, occludin, and ZO- 1 of the blood-brain barrier in a focal cerebral ischemic insult. J Mol Neurosci 2011, 44:130-139.

140. Afonso PV, Ozden S, Prevost MC, Schmitt C, Seilhean D, Weksler B, Couraud PO, Gessain A, Romero IA, Ceccaldi PE: Human blood-brain barrier disruption by retroviral-infected lymphocytes: role of myosin light chain kinase in endothelial tight-junction disorganization. J Immuno/ 2007, 179:2576-2583.

141. Schreibelt G, Kooij G, Reijerkerk A, van Doorn R, Gringhuis SI, van der Pol S, Weksler BB, Romero IA, Couraud PO, Piontek J, et al: Reactive oxygen species alter brain endothelial tight junction dynamics via RhoA, $\mathrm{Pl} 3$ kinase, and PKB signaling. FASEB J 2007, 21:3666-3676.

142. Clarke $H$, Soler AP, Mullin JM: Protein kinase $C$ activation leads to dephosphorylation of occludin and tight junction permeability increase in LLC-PK1 epithelial cell sheets. J Cell Sci 2000, 113(Pt 18):3187-3196.

143. Sakakibara A, Furuse M, Saitou M, Ando-Akatsuka Y, Tsukita S: Possible involvement of phosphorylation of occludin in tight junction formation. J Cell Biol 1997, 137:1393-1401.

144. Morgan L, Shah B, Rivers LE, Barden L, Groom AJ, Chung R, Higazi D, Desmond H, Smith T, Staddon JM: Inflammation and dephosphorylation of the tight junction protein occludin in an experimental model of multiple sclerosis. Neuroscience 2007, 147:664-673. 
145. Ishizaki T, Chiba H, Kojima T, Fujibe M, Soma T, Miyajima H, Nagasawa K, Wada I, Sawada N: Cyclic AMP induces phosphorylation of claudin-5 immunoprecipitates and expression of claudin- 5 gene in blood-brain-barrier endothelial cells via protein kinase A-dependent and -independent pathways. Exp Cell Res 2003, 290:275-288

146. Bruckener KE, El Baya A, Galla HJ, Schmidt MA: Permeabilization in a cerebral endothelial barrier model by pertussis toxin involves the PKC effector pathway and is abolished by elevated levels of cAMP. J Cell Sci 2003, 116:1837-1846.

147. Desai TR, Leeper NJ, Hynes KL, Gewertz BL: Interleukin-6 causes endothelial barrier dysfunction via the protein kinase $C$ pathway. J Surg Res 2002, 104:118-123.

148. Andreeva AY, Krause E, Muller EC, Blasig IE, Utepbergenov DI: Protein kinase $C$ regulates the phosphorylation and cellular localization of occludin. J Biol Chem 2001, 276:38480-38486.

149. Stuart RO, Nigam SK: Regulated assembly of tight junctions by protein kinase C. Proc Natl Acad Sci USA 1995, 92:6072-6076.

150. Hofmann J: The potential for isoenzyme-selective modulation of protein kinase C. FASEB J 1997, 11:649-669.

151. Fleegal MA, Hom S, Borg LK, Davis TP: Activation of PKC modulates blood-brain barrier endothelial cell permeability changes induced by hypoxia and posthypoxic reoxygenation. Am J Physiol Heart Circ Physiol 2005, 289:H2012-2019.

152. Andreeva AY, Piontek J, Blasig IE, Utepbergenov DI: Assembly of tight junction is regulated by the antagonism of conventional and novel protein kinase C isoforms. Int J Biochem Cell Biol 2006, 38:222-233.

153. Harrington EO, Brunelle JL, Shannon CJ, Kim ES, Mennella K, Rounds S: Role of protein kinase $C$ isoforms in rat epididymal microvascular endothelial barrier function. Am J Respir Cell Mol Biol 2003, 28:626-636.

154. Sonobe Y, Takeuchi H, Kataoka K, Li H, Jin S, Mimuro M, Hashizume Y, Sano $Y$, Kanda T, Mizuno T, Suzumura A: Interleukin-25 expressed by brain capillary endothelial cells maintains blood-brain barrier function in a protein kinase Cepsilon-dependent manner. J Biol Chem 2009, 284:31834-31842.

155. Goldstein B, Macara IG: The PAR proteins: fundamental players in animal cell polarization. Dev Cell 2007, 13:609-622

156. Coureuil M, Mikaty G, Miller F, Lecuyer H, Bernard C, Bourdoulous S, Dumenil G, Mege RM, Weksler BB, Romero IA, et al: Meningococcal type IV pili recruit the polarity complex to cross the brain endothelium. Science 2009, 325:83-87.

157. Iden S, Rehder D, August B, Suzuki A, Wolburg-Buchholz K, Wolburg $H_{t}$ Ohno S, Behrens J, Vestweber D, Ebnet K: A distinct PAR complex associates physically with VE-cadherin in vertebrate endothelial cells. EMBO Rep 2006, 7:1239-1246.

158. Birukova AA, Smurova K, Birukov KG, Kaibuchi K, Garcia JG, Verin AD: Role of Rho GTPases in thrombin-induced lung vascular endothelial cells barrier dysfunction. Microvasc Res 2004, 67:64-77.

159. Boivin D, Bilodeau D, Beliveau R: Regulation of cytoskeletal functions by Rho small GTP-binding proteins in normal and cancer cells. Can J Physiol Pharmacol 1996, 74:801-810.

160. Stamatovic SM, Keep RF, Kunkel SL, Andjelkovic AV: Potential role of MCP-1 in endothelial cell tight junction 'opening': signaling via Rho and Rho kinase. J Cell Sci 2003, 116:4615-4628.

161. Persidsky Y, Heilman D, Haorah J, Zelivyanskaya M, Persidsky R, Weber GA, Shimokawa H, Kaibuchi K, Ikezu T: Rho-mediated regulation of tight junctions during monocyte migration across the blood-brain barrier in HIV-1 encephalitis (HIVE). Blood 2006, 107:4770-4780.

162. Adamson P, Etienne S, Couraud PO, Calder V, Greenwood J: Lymphocyte migration through brain endothelial cell monolayers involves signaling through endothelial ICAM-1 via a rho-dependent pathway. J Immunol 1999, 162:2964-2973.

163. Etienne S, Adamson P, Greenwood J, Strosberg AD, Cazaubon S, Couraud PO: ICAM-1 signaling pathways associated with Rho activation in microvascular brain endothelial cells. J Immuno/ 1998, 161:5755-5761.

164. Engelhardt B, Wolburg H: Mini-review: Transendothelial migration of leukocytes: through the front door or around the side of the house? Eur J Immunol 2004, 34:2955-2963.

165. Goeckeler ZM, Wysolmerski RB: Myosin light chain kinase-regulated endothelial cell contraction: the relationship between isometric tension, actin polymerization, and myosin phosphorylation. J Cell Biol 1995, 130:613-627.
166. Hixenbaugh EA, Goeckeler ZM, Papaiya NN, Wysolmerski RB, Silverstein SC, Huang AJ: Stimulated neutrophils induce myosin light chain phosphorylation and isometric tension in endothelial cells. Am J Physiol 1997, 273:H981-988.

167. Moy AB, Shasby SS, Scott BD, Shasby DM: The effect of histamine and cyclic adenosine monophosphate on myosin light chain phosphorylation in human umbilical vein endothelial cells. J Clin Invest 1993, 92:1198-1206.

168. Antonetti DA, Barber AJ, Hollinger LA, Wolpert EB, Gardner TW: Vascular endothelial growth factor induces rapid phosphorylation of tight junction proteins occludin and zonula occluden 1. A potential mechanism for vascular permeability in diabetic retinopathy and tumors. J Biol Chem 1999, 274:23463-23467.

169. Nico B, Mangieri D, Crivellato E, Longo V, De Giorgis M, Capobianco C, Corsi $P$, Benagiano V, Roncali L, Ribatti D: HIF activation and VEGF overexpression are coupled with ZO-1 up-phosphorylation in the brain of dystrophic mdx mouse. Brain Pathol 2007, 17:399-406.

170. Kago T, Takagi N, Date I, Takenaga Y, Takagi K, Takeo S: Cerebral ischemia enhances tyrosine phosphorylation of occludin in brain capillaries. Biochem Biophys Res Commun 2006, 339:1197-1203.

171. Wang W, Dentler WL, Borchardt RT: VEGF increases BMEC monolayer permeability by affecting occludin expression and tight junction assembly. Am J Physiol Heart Circ Physiol 2001, 280:H434-440.

172. Frank PG, Woodman SE, Park DS, Lisanti MP: Caveolin, caveolae, and endothelial cell function. Arterioscler Thromb Vasc Biol 2003, 23:1161-1168.

173. Sprenger RR, Fontijn RD, van Marle J, Pannekoek H, Horrevoets AJ: Spatial segregation of transport and signalling functions between human endothelial caveolae and lipid raft proteomes. Biochem J 2006, 400:401-410.

174. Nusrat A, Parkos CA, Verkade P, Foley CS, Liang TW, Innis-Whitehouse W, Eastburn KK, Madara JL: Tight junctions are membrane microdomains. J Cell Sci 2000, 113(Pt 10):1771-1781.

175. Shen L, Turner JR: Actin depolymerization disrupts tight junctions via caveolae-mediated endocytosis. Mol Biol Cell 2005, 16:3919-3936.

176. Andras IE, Pu H, Deli MA, Nath A, Hennig B, Toborek M: HIV-1 Tat protein alters tight junction protein expression and distribution in cultured brain endothelial cells. J Neurosci Res 2003, 74:255-265.

177. Urban NT, Willig KI, Hell SW, Nagerl UV: STED nanoscopy of actin dynamics in synapses deep inside living brain slices. Biophys J 2011, 101:1277-1284.

178. Keene SD, Greco TM, Parastatidis I, Lee SH, Hughes EG, Balice-Gordon RJ, Speicher DW, Ischiropoulos H: Mass spectrometric and computational analysis of cytokine-induced alterations in the astrocyte secretome. Proteomics 2009, 9:768-782.

179. Picotti P, Aebersold R: Selected reaction monitoring-based proteomics: workflows, potential, pitfalls and future directions. Nat Methods 2012, 9:555-566.

180. Uchida Y, Ohtsuki S, Katsukura Y, Ikeda C, Suzuki T, Kamiie J, Terasaki T: Quantitative targeted absolute proteomics of human blood-brain barrier transporters and receptors. J Neurochem 2011, 117:333-345.

\section{doi:10.1186/2045-8118-9-23}

Cite this article as: Luissint et al:: Tight junctions at the blood brain barrier: physiological architecture and disease-associated dysregulation. Fluids and Barriers of the CNS 2012 9:23.

\section{Submit your next manuscript to BioMed Central and take full advantage of:}

- Convenient online submission

- Thorough peer review

- No space constraints or color figure charges

- Immediate publication on acceptance

- Inclusion in PubMed, CAS, Scopus and Google Scholar

- Research which is freely available for redistribution 